\title{
Interactive comment on "Airborne measurement of peroxy radicals using chemical amplification coupled with cavity ring down spectroscopy: the PeRCEAS instrument” by Midhun George et al.
}

\section{Anonymous Referee \#1}

Received and published: 19 November 2019

The comment was uploaded in the form of a supplement:

https://www.atmos-meas-tech-discuss.net/amt-2019-359/amt-2019-359-RC1-

supplement.pdf

Interactive comment on Atmos. Meas. Tech. Discuss., doi:10.5194/amt-2019-359, 2019. 